\title{
Features of the structure of vegetative organs Dodartia orientalis L. (Scrophulariaceae Juss.) from different ecological conditions
}

\author{
Vasila Sharipova ${ }^{1 *}$ \\ ${ }^{1}$ Institute of Botany Academy of Sciences Republic of Uzbekistan Str. Durmon Yuli, 32. Tashkent, \\ Uzbekistan, 100125
}

\begin{abstract}
The features of the structure of the leaves of Dodartia orientalis, growing in different ecological conditions have been studied. Haloxeromorphic signs have been mostly revealed in the plants growing in the arid conditions of Ustyurt. Mesomorphic signs have been identified in the plants growing conditions of Tashkent.
\end{abstract}

\section{Introduction}

In recent years, as a result of increased anthropogenic impact, a shortage of plant resources has been manifested, and their productivity and quality have been reduced. The problems of restoring the vegetation cover and increasing its productivity suggest the implementation of special theoretical developments and their practical solutions by selecting certain types of plants for introduction into disturbed communities and creating artificial phytocenoses of various economic uses. In order to fulfill this task, it is advisable to study in nature and identify highly adaptive to harsh living conditions of plants of local flora based on the study of their environmental and functional features. Among the large number of adaptive properties of plants, the physiological functions of plants, closely related to the anatomical and morphological characteristics and underlying their adaptation to living conditions, are of particular importance.

Dodartia is a monotypic genus of herbaceous plants. It includes only one species Dodartia orientalis. Distributed in the European part of Russia, Western Siberia, Ukraine, Central Asia. For therapeutic purposes, grass (stems, leaves, flowers), roots are used. The plant contains cardenolides $(0.6 \%)$, saponins, alkaloids, flavonoid hyperoside, vitamin $\mathrm{C}$, coumarins. In the scientific literature, there is virtually no data on the structure of the autonomic organs of Dodartia orientalis.

\section{Materials and methods}

The objects of study are Dodartia orientalis L. growing in the natural conditions of Ustyurt (Eastern Chink) and in the anthropogenic conditions of Tashkent (along the railway). Material is collected at 2 different points in the habitat. Studied leaves from plants in the flowering phase. Stem leaves from the middle tier of the main shoot. Leaves are fixed in $70 \%$ ethanol. The epidermis was studied on paradermal and transverse sections. Cross sections are made through the middle lobe of the leaf. The preparations are stained with

\footnotetext{
${ }^{*}$ Corresponding author: vasila $82 @$ mail.ru
} 
methylene blue, glued in glycerin-gelatin. Quantitative indicators of signs were measured with a screw eyepiece-micrometer MOV-15 according to the generally accepted method [1]. Mathematical processing was carried out according to the method of G.N. Zaitsev [2] using a personal computer (MS Excel). Microphotographs were taken with a computer microphotograph with a Samsung digital camera.

\section{Results and discussion}

Features of the anatomical structure of the vegetative organs of plants, primarily the structure of the leaf, fully reflect the adaptive capabilities of the growing conditions. The leaf is one of the most plastic organs. Its structures characterize both the environmental and climatic conditions in which the species has developed, and the body's response to environmental conditions. Dodartia orientalis is a perennial, xerophytic, herbaceous plant $25-40 \mathrm{~cm}$ high, bare, sometimes finely and shortly pubescent in the lower part. The root is thick, giving offspring. The stems are numerous, straight, branched from the base.

The leaves of Dodartia orientalis are flat, sessile, spaced, serrated, quickly fall off. Lower leaves opposite, ovate or oblong, widened at the base; the rest are alternate, linearlanceolate or lanceolate. The leaf plate is $1.5-2.5 \mathrm{~cm}$ long and $0.2-0.5 \mathrm{~cm}$ wide. One of the adaptations to tolerate prolonged summer drought is dropping leaves with the onset of heat. This phenomenon is very common in the desert. In some desert plants, even part of the young shoots of the current year fall. The developed leaves of $D$. orientalis are formed on the axes of the first order and fall early under the conditions of Ustyurt.

The epidermis is single-row, with a thickened outer wall, pubescent with trichomes. The stomata are numerous on both sides, unloaded, anomocytic and anisocytic. In plants growing under the anthropogenic conditions of Tashkent, the mesophyll is isolatedpalisade, consists of 4-5 rows of the palisade parenchyma: 2-3 rows on the adaxial side, 1-2 rows on the abaxial side. In plants growing on Ustyurt, the mesophyll is dorsiventral, consists of 2-3 rows of palisade parenchyma, 3-4 rows of chlorenchyma (Fig. 1, Table 1). Palisade cells are high, tightly closed with a palisade index of 3-3.5 (Fig. 2).

In the mesophyllum, numerous conducting bundles are surrounded by a parenchymal lining. The central vein protrudes markedly from the abaxial side. In the central vein there is one large collateral conducting bundle.

The base of the stem is round. The epidermis is single-row with a thick cuticle, pubescent with trichomes, stomata are numerous. Under the epidermis are hypodermis, which alternate with 1-2 rows of sclerenchyma. Under the sclerenchyma there are several layers of chlorenchyma and the cortical parenchyma. Peripheral conducting bundles are sclerified, form a continuous circle. Above the phloem of conducting bundles are 1-2 rows of hydrocyte cells and areas of sclerenchyma. Xylem is represented by large, numerous vessels, located in groups and chain. The cells of the core parenchyma are large, thinwalled, with a cavity or densely located. Transformations of the anatomical structure of D. orientalis stems due to leaf loss apparently consisted in an increase in the thickness of the chlorenchy, stomata density, and a change in the stomatal orientation relative to the stalk axis. 

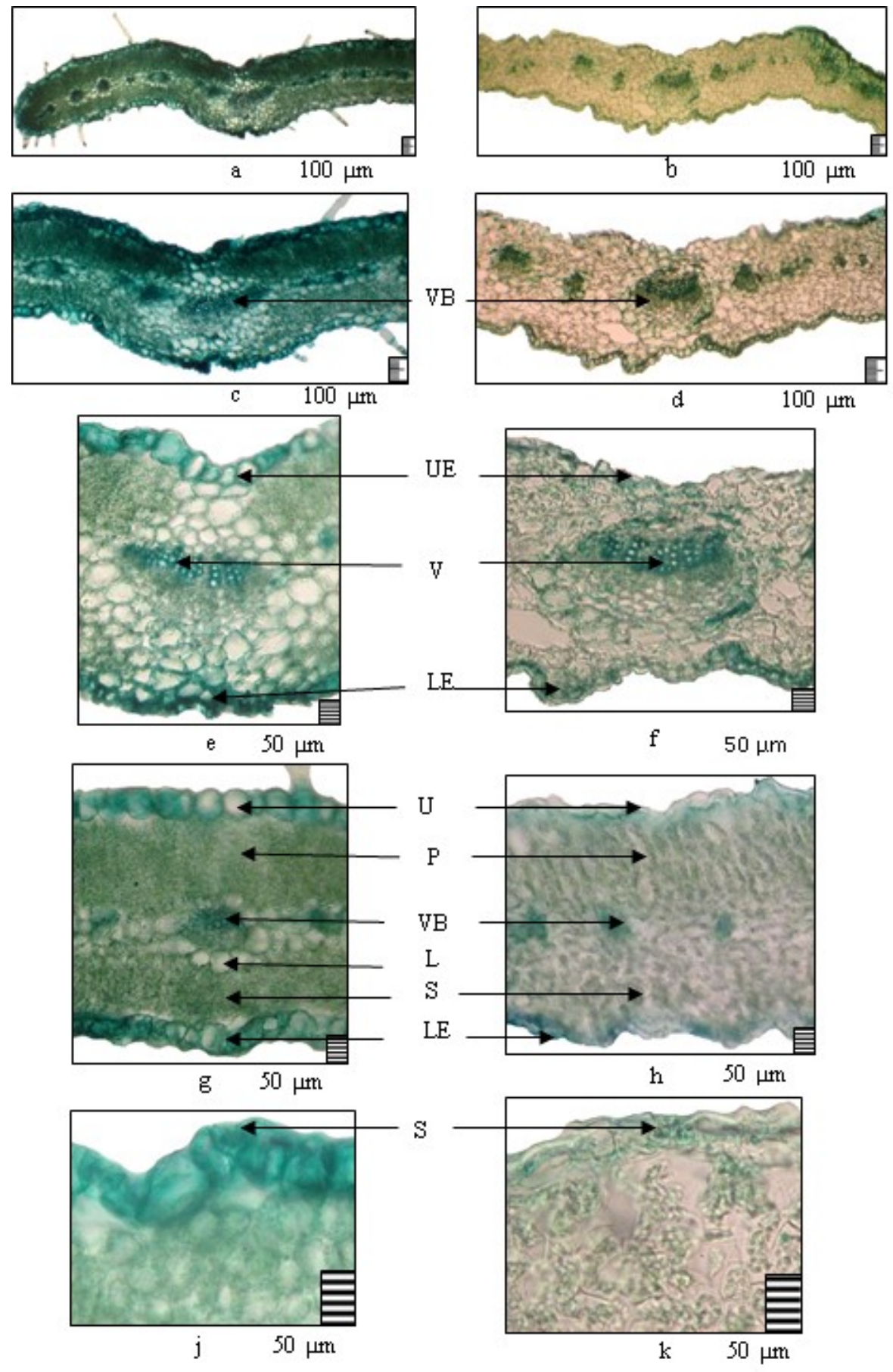

Fig. 1. The structure of the leaf species of Dodartia orientalis from different environmental conditional (Tashkent, Ustyurt): a, c, e, g, j - Tashkent; b, d, f, h, k- Ustyurt. a, b, c, d- general view; e, $\mathrm{f}$ - the main vein; $\mathrm{g}, \mathrm{h}$ - mesophyll; $\mathrm{j}, \mathrm{k}$ - stoma. Legenda: $\mathrm{LE}$ - lower epidermis, $\mathrm{P}$ - palisade parenchyma, S - spongy parenchyma, UE - upper epidermis, V - vessel, VB - vascular bundles. L lining. 


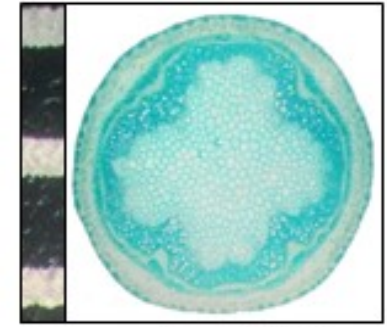

a $100 \mu m$
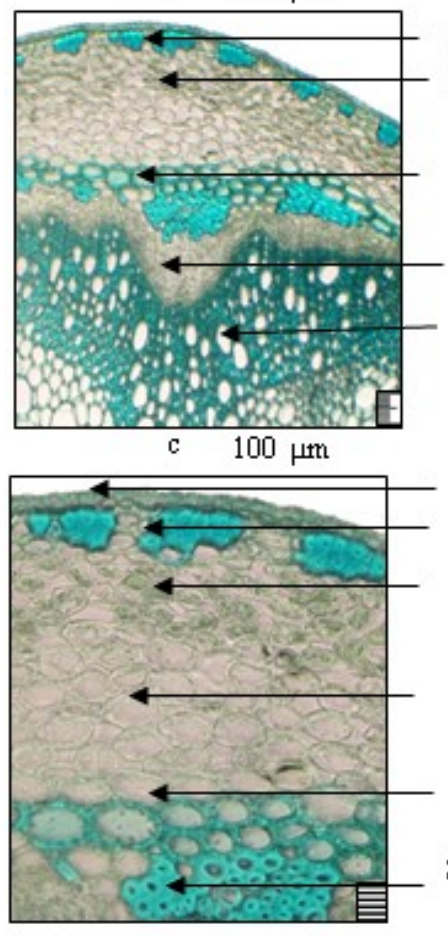

e $\quad 50 \mu \mathrm{m}$

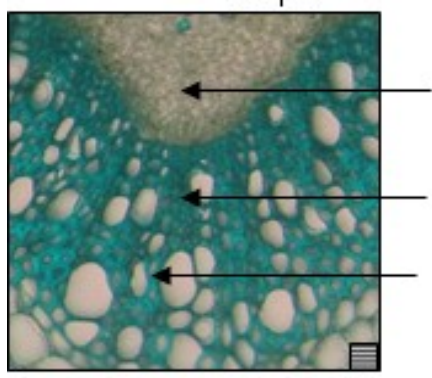

g $\quad 50 \mu \mathrm{m}$

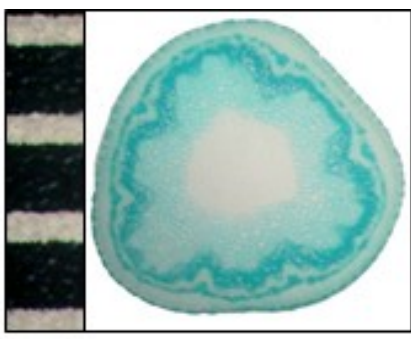

b $100 \mu \mathrm{m}$
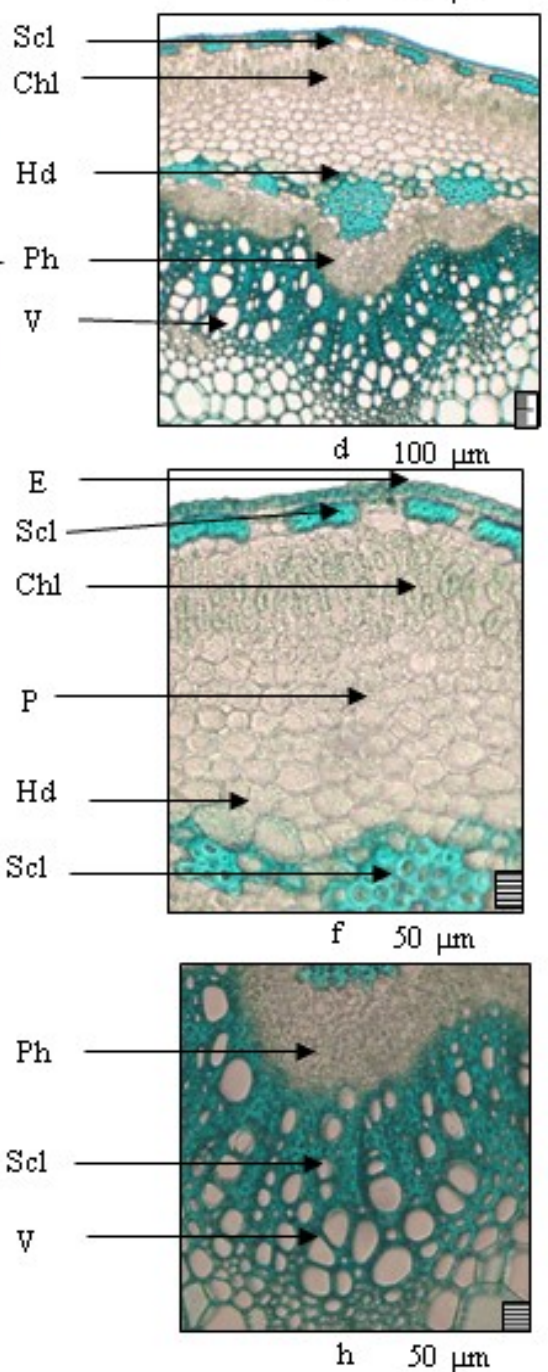

h $50 \mu \mathrm{m}$

Fig. 2. The structure of stem species of Dodartia orientalis from different environmental conditions (Tashkent, Ustyurt): a, c, e, g- Tashkent; b, d, f, h- Ustyurt. a, b-general view; c, d, e, f parenchyma bark; g, $\mathrm{h}$ - vascular bundle.

Legenda: $\mathrm{E}$ - epidermis, $\mathrm{Hd}$ - hydrocyte cells, $\mathrm{Chl}$ - chlorenchyma, $\mathrm{P}$ - palisade parenchyma, $\mathrm{Ph}$ phloem, Scl - sclerenchyma, V - vessel, VB - vascular bundles. 
Table 1. Quantitative indicators of the leaf and stem of Dodartia orientalis species from different environmental conditions

$$
(\mathrm{n}=30)
$$

\begin{tabular}{|c|c|c|c|}
\hline \multicolumn{4}{|c|}{ Leaf plate } \\
\hline \multicolumn{2}{|l|}{ Indicators } & Ustyurt & Tashkent \\
\hline \multicolumn{2}{|l|}{ Length, $\mathrm{cm}$} & $2.1 \pm 0.08$ & $2.3 \pm 0.07$ \\
\hline \multicolumn{2}{|l|}{ Width, cm } & $0.2 \pm 0.05$ & $0.2 \pm 0.06$ \\
\hline \multicolumn{2}{|l|}{ Leaf thickness, $\mu \mathrm{m}$} & $541.8 \pm 4.83$ & $525.6 \pm 4.52$ \\
\hline \multirow{2}{*}{$\begin{array}{l}\text { The thickness of the outer } \\
\text { wall of the epidermis, } \mu \mathrm{m}\end{array}$} & Adaxial & $11.4 \pm 0.16$ & $10.2 \pm 0.16$ \\
\hline & Abaxial & $10.6 \pm 0.14$ & $9.5 \pm 0.12$ \\
\hline \multirow[t]{2}{*}{ Epidermal height, $\mu \mathrm{m}$} & Adaxial & $38.7 \pm 0.31$ & $49.2 \pm 0.42$ \\
\hline & Abaxial & $34.5 \pm 0.28$ & $44.1 \pm 0.39$ \\
\hline \multirow[t]{4}{*}{ Palisade parenchyma } & Cell height, $\mu \mathrm{m}$ & $87.5 \pm 0.81$ & $63 \pm 0.58$ \\
\hline & Width, $\mu \mathrm{m}$ & $25 \pm 0.24$ & $19 \pm 0.22$ \\
\hline & Index & $3.5 \pm 0.08$ & $3,3 \pm 0.07$ \\
\hline & Row & $2-3$ & $4-5$ \\
\hline \multirow[t]{2}{*}{ Vessels in the main vein } & $\begin{array}{l}\text { Quantitative number of } \\
\text { vessels }\end{array}$ & 25 & 27 \\
\hline & $\mathrm{d}-$ vessels, $\mu \mathrm{m}$ & $25.2 \pm 0.25$ & $24.1 \pm 0.25$ \\
\hline \multicolumn{4}{|c|}{ Stem } \\
\hline \multicolumn{2}{|c|}{ Diameter, $\mathrm{cm}$} & $0.35 \pm 0.07$ & $0.30 \pm 0.08$ \\
\hline \multicolumn{2}{|c|}{ The thickness of the outer wall of the epidermis, $\mu \mathrm{m}$} & $12.5 \pm 0.16$ & $11.3 \pm 0.14$ \\
\hline \multicolumn{2}{|c|}{ Epidermal height, $\mu \mathrm{m}$} & $33.3 \pm 0.29$ & $35.3 \pm 0.31$ \\
\hline \multicolumn{2}{|c|}{ Diameter of parenchymal cell, $\mu \mathrm{m}$} & $65.4 \pm 0.59$ & $70.2 \pm 0.66$ \\
\hline \multicolumn{2}{|l|}{ Diameter of vessels, $\mu \mathrm{m}$} & $50.5 \pm 0.47$ & $53.4 \pm 0.51$ \\
\hline
\end{tabular}

\section{Conclusion}

Thus, the leaves of $D$. orientalis according to their morphological and anatomical structure under different environmental conditions had common and distinctive mesomorph and xeromorph characters. Similar signs: leaf length and width, the development of hydrocyte cells, mechanical tissue, lining.

In plants growing on Ustyurt, the signs of xeromorphic are the following: thickening of the leaf, a decrease in the size of the stem, and relatively smaller cell sizes of the leaves and intercellular spaces. Mesomorph signs: mesophyll dorsiventral, unloaded stomata, a large number of stomata on the abaxial side. The increase in the thickness of the chlorenchyma and the density of stomata is probably due to the fact that during the fall of developed leaves the stem fully assumes the function of photosynthesis. Leaf loss is associated with moisture savings due to reduced evaporation surface.

Thus, the complex effect of environmental and anthropogenic factors on the plant is reflected in the complex nature of adaptation. D. orientalis is a plastic species in different environmental conditions. The anatomical and morphological structure of the leaf changes significantly.

This work was supported by the project of F5-FA-0-13289 "Modern trends in the development of vegetation and wildlife of Ustyurt in the process of desertification."

\section{References}

1. R.P.Barykina, N.V. Chubatova A large workshop on the ecological anatomy of flowering plants. (Comrade Scientific KMK, Moscow, 2005)

2. G.N.Zaitsev Mathematics in experimental botany. (Nauka, Moscow, 1991) 